Article

\title{
Can Deliberative Democracy Work in Urban India?
}

\author{
Sanskriti Menon ${ }^{1,2}\left(\mathbb{D}\right.$, Janette Hartz-Karp ${ }^{1}$ and Dora Marinova ${ }^{1, *(\mathbb{D})}$ \\ 1 Curtin University Sustainability Policy Institute, Curtin University, Perth, WA 6845, Australia; \\ sanskriti.menon@ceeindia.org (S.M.); j.hartz-karp@curtin.edu.au (J.H.-K.) \\ 2 Centre for Environment Education, Ahmedabad, Gujarat 380054, India \\ * Correspondence: d.marinova@curtin.edu.au
}

Citation: Menon, S.; Hartz-Karp, J.; Marinova, D. Can Deliberative Democracy Work in Urban India? Urban Sci. 2021, 5, 39. https://doi.org/10.3390/ urbansci5020039

Academic Editor: Simon Springer

Received: 29 March 2021

Accepted: 23 April 2021

Published: 26 April 2021

Publisher's Note: MDPI stays neutral with regard to jurisdictional claims in published maps and institutional affiliations.

Copyright: (C) 2021 by the authors. Licensee MDPI, Basel, Switzerland. This article is an open access article distributed under the terms and conditions of the Creative Commons Attribution (CC BY) license (https:// creativecommons.org/licenses/by/ $4.0 /)$.

\begin{abstract}
India faces extensive challenges of rapid urbanization and deficits in human well-being and environmental sustainability. Democratic governance is expected to strengthen public policies and efforts towards sustainability. This article presents a study in Pune, India, which aimed at exploring perceptions about public participation in urban governance and the potential of high-quality public deliberation to meet deficits. The research reveals disaffection of the public with government decisionmaking and government-led participation. Further, it shows that people are interested in participating in community life and seek to be partners in civic decision-making, but find themselves unable to do so. The study illustrates that high-quality public deliberations facilitated by an independent third party can provide a satisfactory space of participation, learning, and developing balanced outcomes. Citizens expressed readiness for partnership, third-party facilitation, and support from civic advocacy groups. Challenges with regard to government commitment to deliberative democracy will need to be overcome for a purposeful shift from conventional weak to empowered participation of ordinary citizens in civic decision-making. We anticipate that while institutionalization of highquality public deliberations may take time, civil society-led public deliberations may help raise community expectations and demand for induced deliberative democracy.
\end{abstract}

Keywords: deliberative democracy; participation; Pune; sustainability; local government; facilitation

\section{Introduction}

India's cities face extensive and chronic challenges, which are becoming ever more acute with the rapid rate and enormous scale of urbanization. These challenges include the poor quality of life due to the inadequate basic services of water, sanitation, housing and transport, high income inequality, high proportion of informal occupations in urban employment, and increasing pollution [1,2]. With the COVID-19 pandemic, these aspects have become even more pronounced. In this time of climate change and pandemic, focusing on the responsiveness of governance, the sustainability of city infrastructure and the resilience of the livelihoods of urban dwellers, including migrant workers, will be key components of economic recovery [3].

Developing urban resilience is not just complex, it is a "wicked" problem-one that defies simple ways out, since what constitutes the issue varies with the perspective of different stakeholders, and any solution based on a narrow standpoint may exacerbate the problem [4,5]. Rather than empowering citizens to help resolve such "wicked problems", India, the largest democracy in the world, like many other democratic countries, is critiqued for being a "weak democracy", i.e., individualist, conflicted, and with elected governments that diminish the role of citizens [6,7]. This is in contrast with "strong democracy", wherein the citizenship is empowered as much as possible as a way of living [6-9].

India as a democratic nation, like other democracies across the globe, is struggling to embody the principles of governing "by the people, of the people, for the people" [10]. Weak, and even stronger, democracies have tended to give stakeholders in a challenging issue a ritualistic role of "have your say", with little real influence, especially given opaque 
public participation practices, wherein only the loudest, most influential voices are listened to [11-16]. This dilemma has been described as typical of the system's archetype "Fixes that Fail", where the "fix" has the unintended consequences of exacerbating the problem [17,18]. Weymouth and Hartz-Karp [19] suggest that a way to intervene in the "Fixes that Fail" cycle is to purposefully shift from public participation which has little to no impact on a decision, to collaborative and empowered participation of those representative of the population impacted by the issue.

Such empowered participation involves three key principles: representativeness, deliberativeness, and influence $[20,21]$. Representativeness requires the engagement of participants from different backgrounds with diverse perspectives. Deliberativeness involves the time and environment to enable open dialogue and deliberation, with participants having access to user-friendly information, the space to understand and discuss the issues, find options and weigh them against their values to develop recommendations. Influence implies decision-makers making a commitment to consider the deliberation outcomes, and being open to the recommendations having some impact on policy development or decision-making [22]. Such a form of partnership between government and citizens to resolve difficult issues is called deliberative democracy [22]. Over the past few decades, the world has been implementing deliberative democracy as a way forward to address issues of public concern, often "wicked" problems [21,23-25]. In 2020, the Organization for Economic Co-operation and Development (OECD) described this shift as a deliberative wave [26]. Given the success of deliberative democracy initiatives, there are numerous examples of institutionalization, such as the Citizens' Initiative Reviews in Oregon, USA and the permanent Citizens' Council in Ostbelgien, Belgium [27-29].

By contrast, traditional community development approaches, especially top-down, project-induced community participation, adopted by development cooperation agencies have fallen short of achieving equitable and sustainable outcomes [30]. Hence, Mansuri and Rao [30] have called for induced participation efforts to draw upon the spirit of organic participatory change, of learning, experimentation, and persistent engagement, and also to find ways of enabling civic activists to influence government to be more responsive to the needs of citizens.

Inspired by the call from Mansuri and Rao [30], this study conducted in the city of Pune, India aimed to explore the potential for deliberative democracy (DD) initiatives to build upon existing forms of "organic" (community-led) and "induced" (government-led) public participation. Given the complexities of the Indian society, it explored what the nature of high-quality public deliberation would be in this context, and to what extent it would be an effective mechanism for public participation. High-quality public deliberations organized globally usually have an independent entity, referred to as a third party, that conducts the process [26]. Hence, this study also aimed to understand what would constitute an "independent third party" in the context of public participation in the Indian context, and how its contribution could be assessed.

This study was conducted in the city of Pune where one of the authors is based. In recent years, a range of collaborative initiatives of civil-society groups working closely with the municipal government emerged in Pune. These include participatory budgeting [31], integration of informal sector waste pickers into municipal waste management [32], and advocacy on sustainable transportation leading to municipal investment in bus rapid transit [33] among others. A deliberative democracy initiative focused on options for neighborhood street design had also been carried out in Pune in 2013 [34]. However, this was the first study to explore the role of an independent third party within the Indian urban context where deliberative democracy is not institutionalized.

The responsibilities of the municipal government in Pune are vast and range from civic services, including water, waste water, and solid waste management to development of parks and gardens, roads, as well as certain types of welfare schemes. Annual plans and budgets for these services are made by elected and administrative officials. Master plans, made or commissioned by the municipal government, require the approval of the 
state government. The municipal government has the opportunity to enhance public well-being and sustainability, but also faces enormous challenges, such as the scale of the city, availability of funds and capacity to address all issues. Currently, though citizens are invited to submit suggestions for local amenities every year, public participation is not solicited in preparation of long-term or annual plans and budgets for the main civic services. Public participation in longer-term (20 or more years) master plan processes is limited to the submission of suggestions and objections to the already developed documents.

This research led to the realization that to successfully implement deliberative democracy initiatives in the Indian context, it will be important to include India's traditionally strong grassroots organic participation [35]. Additionally, it was realized that it will be important to address the decreasing trust in Indian governments and decision-making [36-38]. One way to address this democratic deficit is via the use of an independent third party [39]. Finally, it has been noted that deliberative democracy is particularly suited for deeply divided societies [40]. In such environments, conflict and polarization can be overcome through facilitated deliberation [40], when a third party, external to any potential divisive issues, can create egalitarian, open discussions based on standard deliberation principles $[22,34]$.

The article provides evidence that lends credibility to and support for these claims. It is important to acknowledge that deliberative democracy, originating from political theory [40], is a normative concept that lays down how political practice should occur, rather than explaining it [41,42]. Hence, it is deeply linked with practice and empirical social science research $[40,41]$. Firstly, the disaffection of the public with government decisionmaking and government-led participation is outlined. Secondly, the article illustrates that people are interested in participating in community life and seek to be partners in civic decision-making, but find themselves unable to do so. Next, it shows that highquality public deliberations can provide a satisfactory space of participation, learning, and developing balanced outcomes.

However, there are challenges with implementing deliberative democracy in urban India with regard to the government not committing to high-quality public participation despite agreeing to do so, and also not acting upon the recommendations when highquality deliberations do get organized by civil society efforts. Hence, the argument that deliberative democracy initiatives could intervene in the "Fixes that Fail" cycle could not be fully tested. However, our data shows that: (1) citizens are ready and capable of taking more empowered roles in resolving complex issues; (2) an independent third party convening the deliberations is supported by participants, increasing their trust in the initiative; and (3) civic advocacy groups are willing to support this effort by having a continued role in developing and implementing high-quality public deliberations, and later, following up on the implementation of recommendations.

The remainder of the article is organized as follows. We first describe the methodology of a case study conducted in Pune, India between 2014 and 2017. Then we present the findings from the research, integrated around eight major themes that emerged from the analysis, namely: disaffection with local government decision-making, desire to participate, high-quality public deliberations, government's ambivalence about public deliberations, role of politicians, citizens' readiness for partnership, third-party facilitation and support from civic advocacy groups. The conclusion draws together the main argument of the article that in the Indian context, the concept of public participation through deliberation would largely depend on organic civic groups being very active for issues of importance to emerge and be taken up as well as to keep the government into account on implementation of deliberative decisions.

\section{Materials and Methods}

This study is based on a case study methodology [43] with the unit of analysis being Pune, a city with a population of about 3.5 million in the state of Maharashtra in western India. Pune is the ninth most populous city in India and has a democratically elected local 
government. In the vein of case study research, a suite of methods was used to best analyze the issue about public participation in civic governance. They include:

- a quantitative survey conducted in Pune in June 2017, referred to as Pune Civic Perceptions Survey 2017, or PCPS 17;

- participants' feedback surveys after three public deliberations in Pune between 2014 and 2017; the deliberated issues were the process of participatory budgeting, street usage, mobility, and design;

- qualitative interviews with knowledgeable individuals, including senior leaders of local non-profit organizations, bureaucrats, and academics conducted between 2014 and 2017;

- qualitative verbal and written comments from support team meetings prior to and following the three public deliberations, including sessions with deliberation observers, facilitators, and advisors conducted between 2014 and 2017.

The findings from the surveys and interviews were analyzed manually using investigator discretion to elicit the main themes emerging from the questionnaires. Quantitative statistics were also generated in response to particular questions. Further information about the specific components of this mixed-methods methodology [44], which allows for a deeper meaning and better understanding about a phenomenon to emerge [45,46], is presented below.

\subsection{Pune Civic Perceptions Survey}

The purpose of the Pune Civic Perceptions Survey was to understand public perceptions about decision-making by the local government in Pune, the extent of public involvement in decision-making, opportunities for participation, as well as the public's interest in participation and ability to participate. There were 19 questions in the survey instrument related to this study. They were linked to civic governance and civic participation covering the following areas: decision-making in Pune, citizens' participation in decision-making in Pune, community engagement with local issues generally and that of the respondent, and the respondent's capacity to contribute to community affairs. Table 1 presents the questions asked together with the responses received.

Table 1. Pune Civic Perceptions Survey, 2017.

\begin{tabular}{|c|c|c|c|c|c|c|}
\hline Survey Questions & Strongly Agree & Agree & Neutral & Disagree & Strongly Disagree & No Answer \\
\hline \multicolumn{7}{|c|}{$\begin{array}{l}\text { To what extent do you agree or disagree with the following statements about the decision-making by Pune Municipal Corporation (PMC) for the } \\
\text { development of the city: }\end{array}$} \\
\hline $\begin{array}{l}\text { Q1.1 Decisions are made in a transparent manner so } \\
\text { that citizens find it easy to understand what } \\
\text { decisions are being made and why. }\end{array}$ & 10 & 98 & 188 & 276 & 25 & \\
\hline $\begin{array}{l}\text { Q1.2 Decisions for the city's development benefit all } \\
\text { sections of society, and especially the poor. }\end{array}$ & 10 & 79 & 189 & 299 & 19 & 1 \\
\hline $\begin{array}{l}\text { Q1.3 The PMC makes efficient use of public money } \\
\text { on different projects and programs. }\end{array}$ & 16 & 123 & 232 & 210 & 16 & \\
\hline $\begin{array}{l}\text { Q1.4 The PMC usually has good reasons for its } \\
\text { decisions, even when those decisions are not popular. }\end{array}$ & 21 & 218 & 289 & 65 & 4 & \\
\hline $\begin{array}{l}\text { Q1.5 The decision-making process at PMC is in great } \\
\text { need of reform. }\end{array}$ & 61 & 325 & 158 & 50 & 3 & \\
\hline \multicolumn{7}{|c|}{$\begin{array}{l}\text { To what extent do you agree or disagree with the following statements about the extent of citizens' participation in decision-making by Pune } \\
\text { Municipal Corporation (PMC): }\end{array}$} \\
\hline $\begin{array}{l}\text { Q2.1 The PMC involves the public in } \\
\text { decision-making. }\end{array}$ & 7 & 57 & 103 & 405 & 25 & \multirow{5}{*}{1} \\
\hline $\begin{array}{l}\text { Q2.2 There are many legal ways for citizens to } \\
\text { successfully influence what local government does. }\end{array}$ & 16 & 226 & 297 & 54 & 4 & \\
\hline $\begin{array}{l}\text { Q2.3 People like me do not have any say about what } \\
\text { the local government does. }\end{array}$ & 34 & 288 & 174 & 94 & 6 & \\
\hline $\begin{array}{l}\text { Q2.4 Local government does not care much about } \\
\text { what a person like me thinks. }\end{array}$ & 34 & 453 & 68 & 40 & 2 & \\
\hline $\begin{array}{l}\text { Q2.5 The vote of a person like me in local } \\
\text { government elections does not make a difference in } \\
\text { influencing local decisions. }\end{array}$ & 21 & 195 & 155 & 222 & 4 & \\
\hline
\end{tabular}


Table 1. Cont.

\begin{tabular}{|c|c|c|c|c|c|c|}
\hline Survey Questions & Strongly Agree & Agree & Neutral & Disagree & Strongly Disagree & No Answer \\
\hline \multicolumn{7}{|c|}{ Thinking about the citizens of Pune community in general, to what extent do you agree or disagree with the following statements: } \\
\hline $\begin{array}{l}\text { Q3.1 People do their part to make their local } \\
\text { community a better place to live. }\end{array}$ & 29 & 254 & 166 & 143 & 5 & \\
\hline $\begin{array}{l}\text { Q3.2 Few people consider voting in local government } \\
\text { elections as an important civic duty. }\end{array}$ & 23 & 234 & 167 & 164 & 9 & \\
\hline $\begin{array}{l}\text { Q3.3 When asked to do their part, most people in } \\
\text { Pune will make personal sacrifices if it benefits the } \\
\text { community. }\end{array}$ & 1 & 31 & 251 & 190 & 115 & 9 \\
\hline \multicolumn{7}{|c|}{ Thinking about your role in your local community, to what extent do you agree or disagree with the following statements: } \\
\hline $\begin{array}{l}\text { Q4.1 People like me play an important role in the life } \\
\text { of my community. }\end{array}$ & 41 & 271 & 246 & 37 & 2 & \\
\hline $\begin{array}{l}\text { Q4.2 I often fail to do my part to make my local } \\
\text { community a good place to live. }\end{array}$ & 9 & 93 & 238 & 245 & 12 & \\
\hline Q4.3 I take my responsibilities as a citizen seriously. & 43 & 335 & 189 & 30 & & \\
\hline \multicolumn{7}{|c|}{ Thinking about yourself, to what extent do you agree or disagree with the following statements: } \\
\hline $\begin{array}{l}\text { Q5.1 I consider myself well-qualified to participate in } \\
\text { politics and community affairs. }\end{array}$ & 22 & 142 & 138 & 283 & 12 & \\
\hline $\begin{array}{l}\text { Q5.2 I have a pretty good understanding of the } \\
\text { important issues facing Pune. }\end{array}$ & 31 & 204 & 283 & 77 & 2 & \\
\hline $\begin{array}{l}\text { Q5.3 I think I am better informed about politics and } \\
\text { government than most people. }\end{array}$ & 14 & 48 & 210 & 316 & 9 & \\
\hline
\end{tabular}

Respondents to the Pune Civic Perceptions Survey were recruited randomly from several different localities well-spread across the city, including a mix of residential, commercial, up-market and poorer areas. The survey generated 597 valid responses, with $38.2 \%$ female and $61.8 \%$ male respondents, resulting in a representative sample of the total city's population at the $95 \%$ confidence level with a confidence interval of 4.01 . There is a sample bias in the number of male and female responses with more men completing the survey. This is likely to be due to the reduced likelihood of encountering women in random selection of respondents in urban public spaces in India. Cluster analysis done to understand patterns of response in relation to gender is discussed in the results section.

\subsection{Public Deliberations}

In rural India, the Gramsabha is a body consisting of persons on the electoral roll of a Panchayat, or a self-governing body, at a village level [47]. The Gramsabha is an empowered local self-government institution in rural areas equivalent to a citizens' assembly. By comparison, cities in India do not have an analogous constitutionally recognized citizens' deliberation forum. This is a critical gap in urban governance in most of India, with only the state of Kerala and a few other instances of urban planning being exceptions. Hence, public deliberation is not institutionalized in Pune. We wanted to understand how urban dwellers in Pune felt about the potential of high-quality public deliberations in addressing governance challenges in the city. It was appropriate to organize such deliberations to help citizens understand the process and its outcomes.

Three deliberation processes were undertaken in Pune between 2014 and 2017 [35,39]. Two of these related to improving the participatory budgeting process in Pune, and the third was on street usage and design in one particular neighborhood (see Boxes 1-3). Each deliberation began with input presentations by experts in the sector. The questions for deliberation were initially discussed by the facilitators and then given to the representative mini-publics [35,39]. Demographically diverse participants were seated in small, purposefully mixed groups, each with a facilitator from an outside organization and a scribe from the participants. The deliberation outputs were put forward and ranked by the participants and later on, formulated into recommendations. A report outlining the deliberation process and the recommendations made was shared with the participants at the end of each event, and then submitted to the city government. 
The Centre for Environment Education (CEE), a non-profit organization in India, supported the arrangement of public deliberations in collaboration with the local nongovernment organization (NGO) Parisar-a community-based partnership working on lobbying and advocacy for sustainable development established in Pune in the early 1980s, and academic institutions, namely Curtin University from Australia and Tata Institute of Social Sciences (TISS) based in Mumbai, India. They acted as third-parties in the deliberation processes.

Detailed descriptions of these deliberations are presented in previous publications by Menon and Hartz-Karp [35,39,48], including brief assessments, learnings from each case, and explanations about how the principles of high-quality public deliberation were applied in the conduct of these forums. What is of interest to this article are the participants feedback surveys implemented after each public event which have not been previously analyzed. The feedback surveys contained questions on inclusivity, deliberation quality, fairness, satisfaction with the deliberation process, and influence of the process on decisionmaking. There were 18, 26, and 33 completed participant responses received from the three forums, respectively. The findings from these surveys are presented in the results section.

Box 1. Public Deliberation to Review Participatory Budgeting in Pune, 2014.

Context: The Pune Municipal Corporation initiated a form of participatory budgeting (PB) in 2007 which included a simple form to make suggestions for neighborhood amenities, and an allocation of funds to each electoral ward. It allows the public to organize studies, discussions, submit suggestions individually or collectively, though no such processes are proactively organized by the local government. This was a commendable step by the local government. However, due to lack of publicity, lack of administrative support, and non-transparent procedures, the provision has been used sub-optimally and has seen very limited participation in recent years.

Public Deliberation: With the intent of revitalizing Pune's participatory budgeting process, a public deliberation to refine PB protocols was organized by the Centre for Environment Education (CEE), a local NGO. Twenty-four participants were recruited to elicit diversity in terms of age, gender, and economic background, ensuring representation of those normally excluded from such processes. This was done mainly by inviting participation from informal sector workers' associations, community groups and organizations working with people with disabilities. Presentations were made about the Pune Participatory Budget history and performance and global best practices. The participants were seated in small groups, ensuring diversity. Each group had a facilitator to support the deliberations and to document the outputs of their discussions. Care was taken to provide each participant adequate opportunities to share and discuss their views. The facilitators also managed translations where needed. The topic of deliberation was: 'How can Pune Participatory Budget be strengthened?' with specific questions on needs' assessment, proposal development, selection and implementation and the annual PB activity cycle. Questions posed included those on needs' assessment, technical soundness and feasibility, prioritization, review of implementation and the annual calendar for PB. The responses from each deliberation question were collated mechanically, while the next questions were posed. All aggregated responses were shared for further deliberation, including prioritization of options. At the end of the day, a Participant Report in Marathi (the local language) and English was disseminated.

Assessment: An assessment of the deliberation was carried out through a feedback form which asked questions about the representativeness, deliberation quality and outcomes of the process. Eighteen forms were received.

Influence: No municipal officials or elected representatives attended this deliberation. Prior to and post deliberation, team sessions were held with the facilitators and observers. The deliberation implementation team identified during the forum was also invited to the post-deliberation team session. As agreed during the public deliberation, the produced Participant Report was submitted to the Municipal Commissioner requesting its implementation. However, this official was soon transferred to another position and a new official assumed responsibility. Thus, despite yielding improvements deemed important by the participants, this deliberative process did not change how the municipality conducted PBs. As organizers, CEE shared the report outputs with the new official too, and as a NGO interested in advancing improvements in PB, it continued to advocate for improved processes. This led to the organization of a second public deliberation on PB in 2015. 
Box 2. Participatory Budgeting Reform in Pune, 2015.

\begin{abstract}
Context: Pune's participatory budgeting has seen limited participation over the years. Local NGOs have felt the need to revitalize this potentially progressive and citizen-empowering provision. With this in view, in 2015, a briefing about the participatory budgeting process in Pune was provided by the Centre for Environment Education (CEE) to the Municipal Commissioner who had recently assumed office.

Public deliberation: An inclusive, deliberative forum was organized with the support of the Municipal Commissioner, who committed to immediately discussing the workshop outcomes with the municipal administration. This public deliberation was facilitated by CEE together with the Curtin University Sustainability Policy Institute and a local NGO, Parisar whose staff had also been involved in the PB facilitation since its inception in Pune. Input presentations about the Pune experience of PB as well as best practices from other parts of the world were made, including the empowered deliberations accompanying PB in Australia. Next, the deliberating group of about 60 participants addressed the following questions: 1/What can we do differently/better in our next Pune $\mathrm{PB}$, given what we have learned from these global and local PB experiences? 2/How can we get more people, including more diverse people involved? 3/How can we structure the PB process so that people can better understand the issues in their ward, and from a more holistic perspective (social, environmental and economic at different scales), and hence make choices that are more informed and considered? 4/ How can we encourage more "shared power" in prioritizing projects and implementing them? The 21st Century Meeting technique was used for deliberations between participants in groups, with facilitators, translators, and scribes entering the group outputs into networked computers. The group outputs were collated and prioritized to yield a printed Participant Report. Assessment: The suggestions and recommendation made by the participating citizens were provided to each of the participants. An assessment of the deliberation was carried out through a feedback form which asked questions about representativeness, deliberation quality, and outcomes of the process. Twenty-four forms were received back.

Influence: This Participant Report was presented to municipal officials and elected representatives during the last session of the deliberative workshop. One promising outcome was that the local government then agreed to prepare a Ward Infrastructure, Services and Environment information base and index (WISE), with CEE as a partner [49]. Using a range of indicators, WISE provided the public with a reference point for the status of civic amenities and services and rationale for budget allocations. The scores for each ward were used to calculate and yield a relative development index. This WISE index was presented by the Municipal Commissioner to the municipal general body during the presentation of the draft budget for the next financial year. However, the elected officials did not fully accept the WISE rationale in the budget proposals [50], so their reasoning behind fund allocations remained opaque to the public.
\end{abstract}

Box 3. Street Design in Aundh, Pune, 2017.

Context: Pune is one of the cities selected for implementation of the Government of India's Smart City Mission. One of the projects implemented under the Smart City Programme was for re-design of streets. A plan for a public deliberation was discussed, to accompany the design process. However, though the local government was initially supportive of a public deliberation, it later withdrew. An excellent tactical urbanism approach was adopted, but the meetings that followed were not inclusive deliberative events, with views of only a few stakeholders being presented. The project was implemented and a highly walkable, attractive environment has been created. However, a range of other related needs that had emerged during the tactical urbanism process beyond the scope of the street design project but within the ambit of the Smart City Programme have remained unmet. About a year later, an opportunity for a public deliberation arose when the Tata Institute of Social Sciences (TISS), a Mumbai-based academic institute, approached the Center for Environment Education (CEE) to support the exploration of the theme of "commoning of governance". The CEE again approached the Smart City authorities to anchor the deliberation, with postgraduate students of public policy as a valuable resource to carry out preparatory activities and assist in the conduct of the deliberation around mobility and street design in the neighborhood. As the authorities remained unresponsive, CEE and TISS decided to host a public event, framing it as a process to develop a citizens' manifesto.

Public deliberation: The question for the deliberation event, which was attended by about 40 demographically diverse participants, was: "How do we, the people representing all those who live and work on or nearby our streets and travel through them, want our streets to be used, designed, developed, and maintained to best meet our needs as a community?" Participants were seated in small groups with facilitators, translators, and scribes. The agreed-upon responses at each table were written on chart sheets and collated on a computer. This made the process somewhat slow, revealing the need for good "civic tech" to support deliberations. A printed Participant Report of the suggestions and recommendation made by the participating citizens was provided to each of the participants.

Assessment: An assessment of the deliberation was carried through a feedback form which asked questions about representativeness, deliberation quality, and outcomes of the process. Thirty-three forms were received back. In addition, two observers provided feedback.

Influence: Soon after the deliberation day, the output was presented to the CEO, Pune Smart City Development Corporation Ltd (PSCDCL). Local newspapers also reported on the studies done by the TISS students and the deliberation event [51]. After receiving the Participant Report, the PSCDCL asked for a detailed report of the studies done prior to the deliberation and of the day itself. The fact that certain segments of society have not been heard was noted and subsequently PSCDCL started organizing monthly and area-wise meetings to present project updates, but these eventually stopped. 


\subsection{Interviews}

A number of qualitative interviews were conducted with a range of individuals knowledgeable about citizen participation in the context of India. These included in-depth, one-on-one interviews with senior leaders of local non-profit organizations, bureaucrats, and academics, that provided broad insights (scribed and later analyzed) on the nature of democracy and public participation in the country and the city. These seven interviews lasted around one hour each and although the interviewees were given an outline of the expected questions, the interviews followed a free format allowing for unrestricted flow of thought.

\subsection{Team Meeting Notes}

Additional, qualitative inputs included documented verbal as well as written comments from support team sessions held prior to and following the three deliberative events, including those of deliberation observers, facilitators, and advisors. Public participation issues raised during these meetings were documented and later analyzed.

\section{Results}

The sections to follow present the findings from the research within the context of Pune and relevant previous studies. They are organized around eight themes which emerged from the analysis. Table 1 specifically summarizes the quantitative responses from the representative Pune Civic Perceptions Survey.

\subsection{Disaffection with Local Government Decision-Making}

The PCPS in 2017 showed that over 60 percent of the respondents felt that government decision-making needed reform. Over 80 percent of them felt that the city's development does not benefit all sections of society and especially the poor, and that decision-making is not transparent. Women tended to be more neutral about government decision-making and "slightly dissatisfied" with opportunities for public participation, while men expressed stronger dissatisfaction. Less than a quarter of the participants were of the opinion that public money is used efficiently.

These findings are similar to surveys conducted across India by the Association for Democratic Reforms in 2013-2014 and 2017. They show dissatisfaction and "below average" scores for all top expectations from government, including employment, healthcare, education, drinking water, roads, public transport, and women's empowerment [36,52]. Another study showed a significantly lower level of trust in government than in NGOs and businesses [38]. Surveys in 2017 and 2018 in India by the Pew Research Center originally indicated high satisfaction with the national government in place after the regime change in 2014, which resulted in a new party system and renationalization [53]. However, the latter survey showed that nearly 69 percent of the respondents felt that the elected leaders are corrupt and noted a marked decline in satisfaction in key sectors of employment, with a high degree of concern in areas related to terrorism and crime $[37,54]$. This dissatisfaction with government also permeated the level of the municipality in Pune as indicated by PCPS 17 and potentially leads to disengagement with democracy, particularly as voting in India is not compulsory.

Voter turnout has been an ongoing concern in Maharashtra [55] and this research identified an underlying reason which can only exacerbate the situation. The PCPS 17 showed that only 52 percent of the participants were inclined to vote in the next election. This compares fairly with the extent of voting in the Lok Sabha (national) election that took place subsequently in the country in 2019, in which voter turnout in Pune was about $50 \%$ [56]. The dissatisfaction of the public is also revealed in the fact that about 167,000 voters opted for "none of the above" option in the last civic polls [57]. An important underlying reason for low voter turnout is the perception among people-over one-third of the respondents in PCPS 17, that their vote does not influence decision-making. Other studies by Parchure et al. $[58,59]$ on why a large proportion of people does not vote in the 
Mumbai and Pune urban regions also reveal the top reasons for not voting include "my vote hasn't changed anything".

\subsection{Desire to Participate}

This disinclination to vote is not however an indication of a lack of interest in democratic governance. On the contrary, people are interested in participating in civic affairs and community life. The PCPS 17 revealed a high level of interest and voluntary participation in community-oriented activities. Over 60 percent of the respondents said they took their responsibilities as citizens seriously and over 50 percent felt that people like them play an important role in community life. Further, there was recognition that other citizens too are concerned about their civic duty and contribute to community improvement. Over 40 percent of the respondents held the view that others do their part to make the community a better place, and even make personal sacrifices for this when asked.

There was also the perception that being involved in the community, both for others and oneself, is more important than voting. About 43 percent of the respondents felt that people do not think voting is important, while almost 67 percent thought people do their part for the community, and over 50 percent thought people in Pune would make personal sacrifices if it would benefit the community.

The desire to participate and the recognition of the role of others are important as they can form the foundation for public deliberation. Using participatory deliberative methods involves not only voicing your own view, but also listening to others and giving due consideration to their perspectives. The appreciation of associational life and community involvement alongside voting for particular representatives is also a key element of democratic life [60]. Some describe this as participation in civil life and argue that this is the way to reform democracies [61]. Such civil life practices represent solidarity and care based on shared moral perceptions.

Most respondents felt that though there are legal ways for citizens to influence local governance, the government in Pune has minimally involved the public. The perception among more than half of the respondents (53 percent) was that ordinary people do not have a say in what their local authorities do. Furthermore, over 80 percent felt the local government did not actually care about their views.

The current mainstream forms of participation were described as inadequate in almost all qualitative interviews. Examples of inadequacies described included: the perspectives of different segments of society are not sought, though they are critical to understanding the problems and to jointly evolving solutions; that the current processes of governmentinduced participation provide no opportunity for public discussion or more thoughtful deliberation, they do not adequately include the voice of marginalized individuals and groups, including new migrants. Further, the extreme "heterogeneity and structural schisms in society" are not addressed adequately in regular participation forums. The complexity of urban issues and the "varied relationships of different segments of society with the city" are overlooked or inadequately considered in the development of solutions. A trend towards erosion of democratic politics and political discussion came up repeatedly in the interviews.

Hence, against broad disaffection with government decision-making and a perception that one's vote does not impact democratic processes, people do have an interest in community life and do their part. They also recognize the same about others in the community, but have little influence on government decision-making, particularly in the absence of effective ways to engage with the public.

\subsection{High Levels of Acceptance of Public Deliberations}

The participant surveys conducted at the end of each deliberative forum indicate that high-quality public deliberations can provide a satisfactory space for participation, learning, and developing balanced outcomes. For example: 
- In all cases, over 80 percent of the participants felt that they had adequate opportunities to speak, were treated with respect, and listened carefully to others;

- In all cases, at least about 85 percent of the participants were satisfied with the deliberation;

- Over 90 percent of the participants in the case where this issue was explored found their learning to be adequate;

- All participants in the case where this issue was explored were satisfied with the neutrality of the facilitators.

At the third deliberation event (which took place in 2017), several participants, facilitators, and two observers (a professor at a higher education institute and a researcher at the government academy for in-service training of administrators, who were requested to critically observe the deliberations for fairness, deliberative quality, facilitation, etc.) expressed their opinion that there is need for repeated consultations under the same format. They observed that participation in such events contributes to civic capacity or the democratic ability of citizens and noted the merit of such a process in yielding better discussion outcomes as compared to other public meetings that were generally held in Pune. The post-event feedback survey provided convincing evidence that high-quality public discussions as the ones occurring during deliberative events improve the ability to generate better recommendations for more sustainable urban living. Below are some indicative quotes:

- " all segments of society were invited and given an equal opportunity to speak and all views were heard";

- "first-hand experience of witnessing individuals to discuss issues affect(ing) their daily lives as well as the free forum in which their views could be presented without the chance of their voices being drowned out by others";

- " "... experience(d) first-hand the ability of citizens to come together and interact, something which was considered impossible by me before this".

\subsection{Government's Ambivalence about Public Deliberations}

An important aspect of deliberative democracy is its ability to influence public policy. The implementation of deliberative democracy in Pune has had some success, but has also seen some ambivalence on the part of the authorities. Below are some examples which support this finding.

One high-quality deliberation, namely the 2015 review of participatory budgeting (see Box 2), was supported by the local government. Administrative officials were present throughout the deliberation, and elected officials joined in when the recommendations were presented by the deliberating mini-public. The recommendations were reviewed and selected measures were taken up for implementation. For example, one promising outcome was that the local government agreed to prepare a Ward Infrastructure, Services and Environment information base and index (WISE), with CEE as a partner [49]. However, later the elected officials did not fully accept the WISE rationale in the budget proposals [50], so their reasoning behind fund allocations remained opaque to the public. This highlighted that without institutionalizing an urban government reform that gives a status and obligations related to the influence of such public deliberations, implementation of good governance, and desired outcomes would remain tenuous.

Another challenge was with regard to the government not formally committing to high-quality public participation, since particular outcomes could not be guaranteed. For example, one of the projects implemented under the Smart City Programmes was the re-design of streets, which became the context for another public deliberation (see Box 3). Though the Pune Smart City Development Corporation Ltd (PSCDCL) did take note of the recommendations of the deliberation, and even started holding regular meetings for some months, actions suggested for street improvement were not implemented or discussed further with the public. This case highlights that organic groups can try to remain engaged with city authorities and pursue resolution of civic issues including 
through public deliberations. However, civil society-led deliberations can only go so far in developing solutions and following up with civic authorities. Eventually, institutional embedding is necessary for deliberative democracy to yield results for urban sustainability in India.

Thus, the public deliberation initiatives in Pune have had mixed support from the government. While the city government has sometimes collaborated in the conduct of public deliberations, and also taken up selected recommendations from such forums, there is no formal method of arranging public deliberative events with a certain quality standard and procedure. These experiences underscored the need for ongoing engagement of civic advocacy groups with the government, in order for the city to benefit from the results of high-quality public deliberations.

\subsection{Role of Politicians}

Deliberation efforts have both received excellent support as well as faced difficulties with politicians. In at least one of the Pune cases presented here, and in an earlier experience [34], politicians played a key role in supporting as well as opposing public deliberation. In the case where politicians played a supportive role, the researchers had detailed prior conversations with local councilors as well as a member of parliament. These politicians were highly supportive of the deliberation, stayed and observed the proceedings for a considerable time, and also made efforts to obtain funding for implementation of the generated recommendations.

Other efforts for deliberations on the citizens' budget suggestions sometimes encountered opposition. For example, prior to the public deliberation on participatory budgeting in 2014, the facilitators team had attempted to arrange a public meeting to review and prioritize the citizens' budget suggestions for that ward. However, soon after the meeting began, an elected official arrived at the venue and disrupted the deliberation, stating that making such decisions was the role of elected officials and not of the public. In this case, the researchers had not reached out to councilors to participate in the prioritization meeting.

The role of politicians vis-a-vis deliberative democracy experience in other countries has similarly been both positive and constraining. For example, it was a member of parliament who provided the enabling context for the first efforts of deliberative democracy in Western Australia [18,62]. More recently, politicians have been deliberants in the public deliberations for constitutional reform in Ireland, with research showing that they did not bias the discussions and instead helped keep them grounded [63]. Niesson's study in Belgium shows that politicians and stakeholders may oppose public deliberations if they aim to have a role in political decision-making beyond occasional, consultative uses [64]. The study also suggests that mini-publics may lead to reflection about the democratic quality of the overall political system, which may be an even more important outcome [64] As such, the relationship of politicians and elected representatives with high-quality public deliberations of ordinary citizens is an important area for further research and practice in the Indian context. The longer-term experiences of participatory planning in Kerala and more recently of participatory budgeting in Delhi [65] may be fertile ground for such further exploration.

\subsection{Citizens' Readiness for Partnership}

Though the municipal government has been ambivalent towards the implementation of high-quality public deliberations, citizens have desired a much more active role in civic decision-making. The public perceptions survey conducted in 2017 included a question on the current experience of participation in civic decision-making, and what was desired. This question used the Arnstein Ladder of Citizen Participation [66] to show different levels of participation-from manipulation and therapy (levels 1 and 2, also deemed nonparticipation) to informing, consultation, and placating (levels 3 to 5 , with a degree of tokenism) to partnership, delegated power, and citizen control (levels 6 to 8 , with a degree 
of citizen power), which respondents could select. Such a tool has been used in studies elsewhere, and enables comparison [67-69].

The survey results showed a gap between the experienced reality of participation and expectation, measured using the Arnstein Ladder [66]. The difference, termed the Arnstein Gap, in Pune is that people experience participation as "informing" and "consultation" by the local government (with a mean score of 3.6), while their expectation is towards "partnership" (mean score of 5.5) [48]. The mean was calculated by ascribing the value of the levels from 1 to 8 . Overall, there is a desire for more engaged and collaborative forms of participation. These results match findings of studies in Geraldton, Australia, which showed a community preference for a partnership and an experienced reality between informing and consultation [69]. Similar findings were obtained in studies carried out in the United States around transportation planning [67].

\subsection{Third-Party Facilitators}

Given the distrust between the public and city government which appears to manifest in both directions, one aspect of the research was to explore the acceptability of an independent third party to be tasked with overseeing good governance [39]. The need for an independent third party was explored with the participants in their feedback following the three deliberative events, as well as in the interviews with key informants and knowledgeable individuals, including NGO leaders, bureaucrats, and academics. Such an independent third party included as an integral part of the public participation process could help provide research on deliberation topics, map stakeholders, hold preparatory meetings with different stakeholders, especially marginalized groups, help in the framing of deliberations, preparing materials for the public to review, as well as design the deliberation process and its evaluation method. Further, such a third-party facilitator could keep track of the implementation of recommendations and impacts, and report learning with suggested changes or adaptations for the future [39].

Participant feedback indicated a clear preference that public deliberations should be facilitated by independent third parties. In one event, over 83 percent felt it was very important or somewhat important, while only 6 percent felt that a third party was not important and 11 percent were undecided. In another event, about 80 percent of the participants felt this was important. Many gave additional feedback that it is very important to have an independent third-party coordinator to achieve a neutral solution. While the option of local government as a coordinator was not ruled out, the preference was for a third party.

The team of observers in the deliberation in 2017 felt that the facilitator role played by a third party was carried out well. Further, they suggested that the local government "may need to be counselled and trained to not become adversaries of this process or of citizens, in this process", and that "initially the government may not be able to actively coordinate/facilitate". Another input was that NGOs, informal coalitions of citizens, or residents' organizations can play the role of coordinator in the initial phase. Eventually when the utility of these consultations is established, then they can be coordinated by the government. However, the role of facilitators should be given to independent persons.

Furthermore, the key informants similarly confirmed the need for an agency that can be a facilitator, mediator, or independent third party, to design and conduct inclusive, well-structured, fair participatory processes. Suggestions for the scope of work of such independent third parties included support for background research, preparation of information materials, design of participation processes, and facilitation. They also provided several suggestions for the qualities of agencies that may implement public deliberation. These included normative qualities, such as a sense of justice, honesty and openness, positionality, especially that such agencies should not be caught up in issues themselves and are trusted by people, as well as having functional capabilities related to organizing and facilitating deliberations. These pertain primarily to the abilities of organizations that may perform the role of independent third parties. 
The qualities of individual facilitators are also crucial in effective deliberations. At the practice level, facilitators must have a dual expertise: on the one hand, they must introduce some informational equality among deliberants, and on the other, they must have processual expertise [70]. Crompton et al. [71] showed how deliberation can be rendered ineffective if crucial technical topics are not presented in easily understandable forms for participants, as well as the dominance of those with more knowledge or power. According to Mansbridge et al. [72], the facilitators' task can be seen as to get "as many relevant and useful ideas as possible out of the group". They also suggested that instrumentally, the facilitators' role involves maintaining the atmosphere of the deliberation so as to enhance (or not impede) the productivity of the deliberating group [72].

On the other hand, Spada and Vreeland [73] highlighted the effect of non-neutral moderators, and found that they can significantly influence participant attitudes and behaviors, including through endorsing or arguing for certain views. They flag the role of moderators as a potential vulnerability that may be exploited by interest groups.

The experience gained in the action research in Pune helped add to this list of qualities, especially the ability to enable each participant to have fair opportunities to express their views and balancing power, e.g., between street vendors and political leaders who may be running a protection racket or collecting rent illegally. Cultural and "street" awareness of perceptions and relationships between different segments of society, such as of caste and gender, seemed important for the facilitator to be able to address subtle power relations that may not be apparent. Table 2 presents a list of the qualities of third-party facilitators.

Table 2. Qualities of third-party facilitators.

Normative qualities

- $\quad$ Basic human qualities of honesty, openness, enthusiasm for public involvement, and not as a mechanical process

- $\quad$ Sense of sustainability, equity, and justice

- Understands that sharing power is not a loss of power

Positionality

- Has the trust and confidence of people

- Not caught up in issues themselves, not attached to particular fields or solutions

Functional capabilities

- $\quad$ Clarity of purpose and process

- Ability to collect relevant information, collate, analyze, present it in ways that people can understand and respond to

- Facilitation skills, including maintaining group atmosphere and free-flow of discussion, ability and patience to listen, and draw out relevant and useful ideas out of the deliberators

- Awareness of cultural, political or other impedances to free-flow of ideas and the ability to work around these to enable open, frank, and equal discussions

- Ability to deal with and to resolve conflict

- Ability to move the deliberation process forward, to consensus or common ground, and decisions or recommendations based on such common ground

As deliberative democracy unfolds in India and around the world, the role of promoters, third-party agencies, the team of facilitators, and individual facilitators will be a critical area needing further research. With progress in institutionalizing participation and public deliberative processes therein, governments may eventually need to set up independent commissions or entities, under whose aegis such deliberations may be held. In the interim, universities, NGOs or other independent research entities that enjoy public trust may well play the role of such third parties, at least at the outset [39].

\subsection{Support from Civic Advocacy Groups}

Civic advocacy groups have been willing to support the advocacy for instituting highquality public deliberations in Pune [48]. They have also insisted on having a continued 
role in developing and implementing public high-quality deliberations, and later, following up on the implementation of recommendations.

For example, after the public deliberation in 2015, once the municipal administration indicated an interest in the preparation of the WISE index, the NGO Centre for Environment Education formulated a collaborative initiative, consulting experts in the field and working in close coordination with the municipal accounts department, line departments and ward offices. Civic groups working on sectoral issues, such as sustainable mobility, also advocated for including public deliberations in planning processes they were working on, such as for a bicycle plan for Pune and a business plan for the public bus utility. A senior staff member of a partner NGO in a later interview, said:

"The fact [is] that a few deliberations therefore happened around the bicycle plan or were supposed to happen around the PMPML (Pune Mahanagar Parivahan Mahamandal Ltd, the public transport bus service) business plan was, because an organization felt that this is an important process and pushed for it. If every advocacy group did that, then you would see a lot more deliberations happening which is another way to promote the idea of deliberative decision-making."

\section{Discussion and Conclusions}

This research confirmed the relevance of introducing deliberative democracy in Indian urban areas: disaffection with government-led participation, exclusions in and disaffection with electoral processes. A reform of the governance systems in Indian cities is needed to enable citizens to be embedded in decision-making about complex issues of urban sustainability. Collaborative, dialogue-based approaches have been posited as appropriate to address wicked problems, as presented in Menon and Hartz-Karp [39]. Mansuri and Rao [30] called for induced participatory projects to draw upon the spirit of organic participatory change, of learning, experimentation, and persistent engagement, and also to find ways of enabling civic activists to influence government to be more responsive to the needs of citizens. Social participation has also shown to be a powerful way to improve governance systems and enhance community input in other settings, such as revitalization of rural areas in Spain [74]. This study contended that in the Indian public decision-making context, deliberative democracy may function best as an induced participation process within the representative democratic governance framework of the country, with organic civic groups providing persistent engagement and institutional memory.

The experience and findings from this study are expected to be of relevance and applicability to other Indian cities. Many public and civil-society organizations in Indian cities are struggling with the "Fixes that Fail" archetype of decision-making. Initiating high-quality public deliberations in different urban contexts as informed by this study, together with building upon the processes already underway in Kerala and Delhi would help evolve both theory and practice. Of particular interest would be an examination of how stated political support for public deliberations actually measures up against the criteria of inclusivity, deliberative quality, and influence.

Ideally, induced processes anchored in government would provide unambiguous space, authority and resources for conducting deliberative processes. They would provide information about the issues chosen for deliberation, participate in oversight committees, appoint third-party facilitators, provide grievance redress mechanisms, document the process and make the records publicly available. However, institutionalization of deliberative democracy may take a while to materialize in the Indian urban context.

In the conjoined conceptualization of participation, organic civic groups would play a key role, providing strength and meaning to public deliberation. They would help surface issues for deliberation, assist in framing, communication about key areas of concern and presenting expert knowledge, and support marginalized and vulnerable segments of society to voice their views. They would participate in decisions on appointment of third-party facilitators, and participate in oversight committees. 
Importantly, such organic civic groups would follow-up to ensure implementation of recommendations, or further deliberations as needed, and keep issues alive, providing continuity between bureaucrats and terms of office of elected representatives. In fact, as the action research in Pune showed, it is almost up to organic civic groups to improve their own methods of bringing about change. Civic groups would need to advocate for embedding public deliberation in public decision-making, and may well have to play all the roles necessary to support the conduct of participatory deliberations.

Within the "organic" sphere of public deliberation in India, a combination between civil society, independent third parties, government, and the broader community could provide the opportunity for an intervention in the "Fixes that Fail" cycle. In the future, organic or civil society-led public deliberation may help raise community expectations on what participation should be like, raising the demand for induced deliberative democracy.

Author Contributions: All authors conceptualized this study; S.M. collected and analyzed the empirical data and drafted the article. All authors made contributions throughout all sections. All authors have read and agreed to the published version of the manuscript.

Funding: This research was funded by AusAID Public Sector Linkages Program Project 65080, Australia-India Council grant number June 14105.

Data Availability Statement: All data is contained within the article.

Acknowledgments: The authors would like to acknowledge the contribution of an Australian Government Research Training Program Scholarship in supporting this research. They are also thankful to all participants in this study, including facilitators and observers. The time cost of facilitators was supported by the Centre for Environment Education, whose contribution is also acknowledged. Many thanks also to the three anonymous reviewers whose comments were very helpful for improving the quality of the manuscript.

Conflicts of Interest: All authors declare no conflict of interest. The funders had no role in the design of the study; in the collection, analyses, or interpretation of data; in the writing of the manuscript, or in the decision to publish the results.

\section{References}

1. Ahluwalia, I.J.; Munjee, N.; Mor, N.; Vijayanunni, M.; Mankad, S.; Lall, R.; Sankaran, H.; Ramanathan, R.; Mathur, O.P.; Srivastava, P.K. Report on Indian Urban Infratsructure and Services. 2011. Available online: https://smartnet.niua.org/sites/default/files/ resources / FinalReport-hpec.pdf (accessed on 10 March 2021).

2. Kapoor, A.; Sinha, H. View: India's Urbanisation Challenges and the Way Forward. 2020. Available online: https: / / economictimes.indiatimes.com/news/economy/policy/view-indias-urbanisation-challenges-and-the-way-forward/ articleshow /79443872.cms (accessed on 10 March 2021).

3. Revi, A.; Ray, M.; Sami, N.; Anand, S.; Mitra, S.; Malladi, T. The Potential of Urbanisation to Accelerate Post-COVID Economic Recovery: Report to the XV Finance Commission. 2020. Available online: https:/ /iihs.co.in/knowledge-gateway/the-potentialof-urbanisation-to-accelerate-post-covid-economic-recovery-report-to-the-xv-finance-commission/ (accessed on 10 March 2021).

4. Rittel, H.W.J.; Webber, M.M. Dilemmas in a general theory of planning. Policy Sci. 1973, 4, 155-169. [CrossRef]

5. Westin, M.; Hellquist, A.; Colvin, J.; Kronlid, D. Towards urban sustainability: Learning from the design of a programme for multi-stakeholder collaboration. S. Afr. J. Environ. Educ. 2014, 29-30, 39-57.

6. Jayal, N.G. Citizenship and Its Discontents: A Indian History: A Indian History; Harvard University Press: Cumberland, MD, USA, 2013; ISBN 978-0-674-06758-5.

7. Kapur, D. Why Does the Indian State Both Fail and Succeed? J. Econ. Perspect. 2020, 34, 31-54. [CrossRef]

8. Prugh, T.; Costanza, R.; Daly, H.E. The Local Politics of Global Sustainability. 2012. Available online: https:/ /islandpress.org/ books/local-politics-global-sustainability (accessed on 15 March 2021).

9. Tolpady, R. Reconstructing Democratic Concerns in India. In Indian Democracy: Problems and Prospects; Manisha, M., Mitra Deb, S., Eds.; Anthem Press: London, UK, 2009; ISBN 978-1-84331-813-2.

10. Abraham Lincoln papers: Series 3. General Correspondence. 1837-1897: Abraham Lincoln. Available online: https://www.loc. gov /item/mal4356600 / (accessed on 15 March 2021).

11. Singh, B. Parallel Structures of Decentralisation in the Mega City Context of Urban India: Participation or Exclusion? Space Polity 2012, 16, 111-127. [CrossRef]

12. Desai, R.; Sanyal, R. Introduction. In Urbanizing Citizenship: Contested Spaces in Indian Cities; Desai, R., Sanyal, R., Eds.; Sage Publications India Pvt Ltd.: New Delhi, India, 2012; pp. 1-28. 
13. Perić, A. Citizen Participation in Transitional Society: The Evolution of Participatory Planning in Serbia. In Learning from Arnstein's Ladder; Routledge: London, UK, 2020; pp. 91-109, ISBN 978-0-429-29009-1.

14. Madero, V.; Morris, N. Public participation mechanisms and sustainable policy-making: A case study analysis of Mexico City's Plan Verde. J. Environ. Plan. Manag. 2016, 59, 1728-1750. [CrossRef]

15. Harrison, P.; Rubin, M.; Appelbaum, A.; Dittgen, R. Corridors of Freedom: Analyzing Johannesburg's Ambitious Inclusionary Transit-Oriented Development. J. Plan. Educ. Res. 2019, 39, 456-468. [CrossRef]

16. Hübscher, M.; Ringel, J. Opaque Urban Planning. The Megaproject Santa Cruz Verde 2030 Seen from the Local Perspective (Tenerife, Spain). Urban Sci. 2021, 5, 32. [CrossRef]

17. Hartz-Karp, J. Harmonising Divergent Voices: Sharing the Challenge of Decision Making. 2004. Available online: https: / / search.informit.org/doi/10.3316/IELAPA.200503318 (accessed on 12 March 2021).

18. Hartz-Karp, J. How and Why Deliberative Democracy Enables Co-Intelligence and Brings Wisdom to Governance. J. Deliberative Democr. 2007, 3, 1. [CrossRef]

19. Hartz-Karp, J.; Weymouth, R.M. Deliberative Democracy-Demographic Renewal Capable of Addressing Sustainability. In Methods for Sustainability Research; Hartz-Karp, J., Marinova, D., Eds.; Edward Elgar: Northampton, MA, USA, 2017 ; pp. 113-128.

20. Fung, A. Deliberation before the Revolution: Toward an Ethics of Deliberative Democracy in an Unjust World. Political Theory 2005, 33, 397-419. [CrossRef]

21. Fung, A.; Wright, E.O. Deepening Democracy: Institutional Innovations in Empowered Participatory Governance; Verso: London, $\mathrm{UK}, 2003$.

22. Gastil, J.; Richards, R. Making Direct Democracy Deliberative through Random Assemblies. Politics Soc. 2013, 41, $253-281$. [CrossRef]

23. Dryzek, J.S.; Bächtiger, A.; Chambers, S.; Cohen, J.; Druckman, J.N.; Felicetti, A.; Fishkin, J.S.; Farrell, D.M.; Fung, A.; Gutmann, A.; et al. The crisis of democracy and the science of deliberation. Science 2019, 363, 1144. [CrossRef]

24. Elstub, S.; Ercan, S.; Mendonça, R.F. Editorial introduction: The fourth generation of deliberative democracy. Crit. Policy Stud. 2016, 10, 139-151. [CrossRef]

25. Weymouth, R.; Hartz-Karp, J. Principles for Integrating the Implementation of the Sustainable Development Goals in Cities. Urban Sci. 2018, 2, 77. [CrossRef]

26. OECD. Innovative Citizen Participation and New Democratic Institutions. Available online: https://www.oecd-ilibrary.org/ content/publication/339306da-en (accessed on 25 April 2021).

27. Knobloch, K.R.; Gastil, J.; Reedy, J.; Cramer Walsh, K. Did They Deliberate? Applying an Evaluative Model of Democratic Deliberation to the Oregon Citizens' Initiative Review. J. Appl. Commun. Res. 2013, 41, 105-125. [CrossRef]

28. Knobloch, K.R.; Barthel, M.L.; Gastil, J. Emanating Effects: The Impact of the Oregon Citizens' Initiative Review on Voters' Political Efficacy. Political Stud. 2019, 68, 426-445. [CrossRef]

29. Niessen, C.; Reuchamps, M. Le dialogue citoyen permanent en Communauté germanophone. Courr. Hebd. Du Cris. 2019, 2426, 5-38. [CrossRef]

30. Mansuri, G.; Rao, V. Localizing Development: Does Participation Work? The World Bank: Washington DC, USA, 2012; ISBN 978-08213-8256-1.

31. Blair, H. Accountability Through Participatory Budgeting in India: Only in Kerala? In Governance for Urban Services: Access, Participation, Accountability, and Transparency; Cheema, S., Ed.; Springer: Singapore, 2020; pp. 57-76, ISBN 978-981-15-2973-3.

32. Chikarmane, P. Integrating Waste Pickers into Municipal Solid Waste Management in Pune, India. 2012. Available online: http:/ / www.wiego.org/sites/default/files/publications/files/Chikarmane_WIEGO_PB8.pdf (accessed on 25 April 2021).

33. Kamath, L.; Burte, H.; Madhale, A.; King, R. Pune: Coalitions, Contradictions, and Unsteady Transformation. 2018. Available online: https:/ / www.wri.org/wri-citiesforall/publication/pune-civil-society-coalitions-policy-contradictions-and-unsteady (accessed on 1 September 2018).

34. Menon, S.; Rapur, S. Deliberative Democracy and Learning for Sustainable Mobility in Pune. In Academia and Communities: Engaging for Change; Fadeeva, Z.L.G., Chhokar, K., Eds.; UNU-IAS: Tokyo, Japan, 2018.

35. Menon, S.; Hartz-Karp, J. Linking Traditional 'Organic' and 'Induced' Public Participation with Deliberative Democracy: Experiments in Pune, India. J. Educ. Sustain. Dev. 2019, 13, 193-214. [CrossRef]

36. ADR All India Survey on Governance Issues and Voting Behaviour; Association of Democratic Reforms: New Delhi, India, 2019.

37. Devlin, K.; Johnson, C. Indian elections nearing amid frustration with politics, concerns about misinformation. Pew Res. Cent. 2019, 25, 2019.

38. Sastry, T. Civil Society, Indian Elections and Democracy Today; Indian Institute of Management Bangalore: Karnataka, India, 2014.

39. Menon, S.; Hartz-Karp, J. Institutional innovations in public participation for improved local governance and urban sustainability in India. Sustain. Earth 2019, 2, 6. [CrossRef]

40. Curato, N.; Dryzek, J.S.; Ercan, S.A.; Hendriks, C.M.; Niemeyer, S. Twelve Key Findings in Deliberative Democracy Research. Daedalus 2017, 146, 28-38. [CrossRef]

41. Hartz-Karp, J.; Marinova, D. Using Deliberative Democracy for Better Urban Decision-Making through Integrative Thinking. Urban Sci. 2021, 5, 3. [CrossRef]

42. Ozanne, J.L.; Corus, C.; Saatcioglu, B. The Philosophy and Methods of Deliberative Democracy: Implications for Public Policy and Marketing. J. Public Policy Mark. 2009, 28, 29-40. [CrossRef] 
43. Yin, R.K. Case Study Research and Applications: Design and Methods, 6th ed.; SAGE Publications, Inc.: Thousand Oaks, CA, USA, 2018; ISBN 978-1-5063-3616-9.

44. Terrell, S. Mixed-Methods Research Methodologies. Qual. Rep. 2012, 17, 254-280.

45. Harrison, R.L.; Reilly, T.M.; Creswell, J.W. Methodological Rigor in Mixed Methods: An Application in Management Studies. J. Mix. Methods Res. 2020, 14, 473-495. [CrossRef]

46. McKim, C.A. The Value of Mixed Methods Research: A Mixed Methods Study. J. Mix. Methods Res. 2017, 11, 202-222. [CrossRef]

47. Constitution of India The Constitution (Seventy-Third Amendment) Act. 1992. Available online: https://legislative.gov.in/ constitution-seventy-third-amendment-act-1992 (accessed on 25 April 2021).

48. Menon, S.; Hartz-Karp, J. Applying mixed methods action research to explore how public participation in an Indian City could better resolve urban sustainability problems. Action Res. 2020, 1476750320943662. [CrossRef]

49. Pune Municipal Corporation. 2015. Available online: http:// opendata.punecorporation.org/PMCReports/PUNE-SCP-VolumeIV-Citizen-Participation.pdf (accessed on 12 March 2021).

50. Gadkari, S. PMC Goes WISE in Budget, Makes Funding Separations. 2016. Available online: https://punemirror.indiatimes.com/ pune/civic/pmc-goes-wise-in-budget-makes-funding-separations/articleshow/50723335.cms (accessed on 18 September 2018).

51. Dharwadkar, J. Interactive Website, PR Team on Cards. The Hindustan Times, 19 October 2017.

52. ADR. Pan India Survey of Governance Issues; Association of Democratic Reforms: New Delhi, India, 2015.

53. Schakel, A.H.; Sharma, C.K.; Swenden, W. India after the 2014 general elections: BJP dominance and the crisis of the third party system. Reg. Fed. Stud. 2019, 29, 329-354. [CrossRef]

54. Stokes, B.; Manevich, D.; Hanyu, C. In India, Modi Still Very Popular. 2017. Available online: https:/ /www.pewresearch.org/ global/2017/11/15/india-modi-remains-very-popular-three-years-in/ (accessed on 15 January 2021).

55. TNN Monday Blues: Voting Slides in Mumbai. Available online: https:/ timesofindia.indiatimes.com/city/mumbai/apathyrears-its-head-again-in-city/articleshow/71696666.cms (accessed on 23 March 2021).

56. Election Commission of India 15. Assembly Segment Wise Information Electors. Available online: https://eci.gov.in/files/file/ 10965-15-assembly-segment-wise-information-electors/ (accessed on 23 January 2020).

57. Pune Municipal Corporation PMC Open Data Store. Available online: http://opendata.punecorporation.org/Citizen/ CitizenDatasets / Index? categoryId=33 (accessed on 9 December 2018).

58. Parchure, R.K.; Phadke, M.V.; Talule, D. Why People Do Not Vote in Municipal Corporation Elections: A Voter-Based Survey in Pune Municipal Corporation; Gokhale Institute of Politics and Economics: Pune, India, 2017; p. 87.

59. Parchure, R.K.; Phadke, M.V.; Talule, D. Why People Do Not Vote in Municipal Corporation Elections: A Voter-Based Survey in Brihanmumbai Municipal Corporation; Gokhale Institute of Politics and Economics: Pune, India, 2017; p. 72.

60. Putnam, R. Bowling Alone: Revised and Updated; Simon \& Schuster: New York, NY, USA, 2020; ISBN 978-1-982130-84-8.

61. Jennings, B. Redoing the Demos. Hastings Cent. Rep. 2021, 51, S58-S63. [CrossRef]

62. Black, D.; Philips, H. Women in the Western Australian Parliament 1921-2012: Alannah Joan Geraldine MacTiernan; Parliament History Project; Parliament of Western Australia: West Perth, Australia, 2012; p. 8.

63. Farrell, D.M.; Suiter, J.; Harris, C.; Cunningham, K. The Effects of Mixed Membership in a Deliberative Forum: The Irish Constitutional Convention of 2012-2014. Political Stud. 2020, 68, 54-73. [CrossRef]

64. Niessen, $\mathrm{C}$. When citizen deliberation enters real politics: How politicians and stakeholders envision the place of a deliberative mini-public in political decision-making. Policy Sci. 2019, 52, 481-503. [CrossRef]

65. Janaagraha Delhi Government Lays the Foundation for Participatory Budgeting. 2016. Available online: https://www.janaagraha. org/delhi-government-lays-the-foundation-for-participatory-budgeting/ (accessed on 10 April 2021).

66. Arnstein, S.R. A Ladder Of Citizen Participation. J. Am. Inst. Plan. 1969, 35, 216-224. [CrossRef]

67. Bailey, K.; Blandford, B.; Grossardt, T.; Ripy, J. Planning, Technology, and Legitimacy: Structured Public Involvement in Integrated Transportation and Land-Use Planning in the United States. Environ. Plan. B Plan. Des. 2011, 38, 447-467. [CrossRef]

68. Weymouth, R.; Hartz-Karp, J.; Marinova, D. Repairing Political Trust for Practical Sustainability. Sustainability 2020, $12,7055$. [CrossRef]

69. Weymouth, R.; Hartz-Karp, J. Participation in planning and governance: Closing the gap between satisfaction and expectation. Sustain. Earth 2019, 2, 5. [CrossRef]

70. Moore, A. Following from the front: Theorizing deliberative facilitation. Crit. Policy Stud. 2012, 6, 146-162. [CrossRef]

71. Crompton, A.; Waring, J.; Roe, B.; O'Connor, R. Are we all on the same page? A qualitative study of the facilitation challenges associated with the implementation of deliberative priority-setting. Public Manag. Rev. 2018, 20, 1623-1642. [CrossRef]

72. Mansbridge, J.; Hartz-Karp, J.; Amengual, M.; Gastil, J. Norms of Deliberation: An Inductive Study. J. Delib. Democr. $2006,2,1$.

73. Spada, P.; Vreeland, J.R. Who Moderates the Moderators? The Effect of Non-neutral Moderators in Deliberative Decision Making. J. Delib. Democr. 2013, 9, 3. [CrossRef]

74. Diaz-Sarachaga, J.M. Combining Participatory Processes and Sustainable Development Goals to Revitalize a Rural Area in Cantabria (Spain). Land 2020, 9, 412. [CrossRef] 